\title{
CONSECRATION AND IDENTITY OF NATIONAL MINORITIES RIGHTS PROTECTION IN THE CONFERENCE FOR SECURITY AND COOPERATION IN EUROPE - CSCE (ORGANIZATION FOR SECURITY AND COOPERATION IN EUROPE - OSCE IN DECEMBER 1994)
}

\section{Tudor Tănăsescu}

\section{T. Tănăsescu}

Faculty of Law, "Bioterra" University of Bucharest, Romania

*Correspondence: Tudor Tănăsescu, 3 Pescăruşului Street, Block B-24, Stair 3, $6{ }^{\text {th }}$ Floor, Apartment 145, Sector 2, Bucharest, Romania

E-mail: tanasescutudor@yahoo.com

\begin{abstract}
Promotion and protection of European identity rights of persons belonging to national minorities are part of human rights protection system developed universally under the United Nations and, respectively, in the Regional Council of Europe, Organization for Security and Cooperation in Europe and other European institutions. International instruments adopted by the OSCE human dimension that is circumscribed, and are political in nature (so there are not treated) contributed to a great extent, the development of catalog rights identity for people who belong to national minorities, the evidence of evolution ordination mechanisms and regulations and safeguarding the rights of the category listed and, last but not least, to outline a programmatic directions and certain standards in this field. Documents to be examined, as well as other regulatory and industry (universal or regional) that aim at protecting minorities "does not authorize any activity that is contrary to fundamental principles of international law, or other obligations under international law or provisions of the Helsinki Final Act, in particular the principle of sovereignty and territorial integrity of states".
\end{abstract}

Keywords: High Commissioner on National Minorities, the standard identity consecration and protection of national minorities, human dimension, persons belonging to national minorities.

\section{Introduction}

Diversity concrete issues and political interests of states and the international community in the consecration identity of national minorities rights protection that until now did not adopt an international convention can be in this matter to the United Nations. We hold attention on this line, as not all regional human rights documents do not contain provisions aimed at national minorities. In this respect are significant regulations such as the American Convention on Human Rights of $1969^{1}$, the African Charter on Human and Peoples of $1981^{2}$ - which treats only the prohibition of mass expulsions for national groups, racial, ethnic or religious, European Convention on Human Rights 1950', a document that requires only association with a "national minority" as a reason for that discrimination is prohibited.

Although the issue of rights of persons belonging to national identity has its global dimension, it has a special significance for Europe. Consequently, it concerns the subject of

\footnotetext{
${ }^{1}$ It was signed on 22 November 1969 at San Jose (Costa Rica), and came into force in 1978. Corrected by 26 member states of the 35 OSA.

${ }^{2}$ Came into force in 1986.

${ }^{3}$ It was adopted in Rome on 4 November 1950 and came into force on 3 September 1953. Romania has rectified the Convention by Law No. 30 of 18.05.1994, published in Official Gazette no.135 of 31.05.1994.
} 
European institutions among which included the Conference for Security and Cooperation in Europe (CSCE / OSCE).

2. Consecration and protection of rights of persons belonging to national identity. These were the attention of the Conference on Security and Cooperation in Europe in Helsinki in $1975^{4}$ and the Vienna Meeting 1989 of the same body, both final documents adopted at the end of the second general meeting of European, including explicit provisions on the rights of persons belonging national minorities.

Biggest leap, however, substantially higher quality than in the protection of national minorities rightly considered that there was at the Copenhagen meeting of the Conference on the Human Dimension of the CSCE (5 to 29 June 1990) where the document was adopted included an important chapter (IV) devoted to national minorities. The act in question in paragraph 30 of that chapter, "The participating States recognize that issues related to national minorities can not be solved satisfactorily only in a democratic political framework based on the rule of law, with an independent judiciary, effective ${ }^{5}$. This framework, shown below, ensures observance of human rights and fundamental freedoms, equal rights and equal among all citizens, free expression of all their legitimate interests and aspirations, political pluralism and social tolerance.

Final Document of the Copenhagen reaffirmed three fundamental principles aimed at minority issues:

- respect for the rights of persons belonging to national minorities as part of human rights generally recognized, is an essential factor for peace, justice, stability and democracy (point 30 paragraph 3);

- equality before the law for all, regardless of ethnic origin and ban all forms of discrimination and forced assimilation attempts (paragraph 31 );

- personal choice of belonging to a national minority, which can result in no disadvantage (point 32, paragraph 1).

- in paragraph 32, paragraph 2 the final document that provides pesoanele belonging to minorities have the right to maintain and develop freely their ethnic, cultural, linguistic or religious and to maintain and develop their culture in any form, safe from any attempts of assimilation against their will. As the identity of these persons rights are stipulated:

- free use of mother tongue, both in private and the public sector (32.1);

- creating and maintaining their own institutions, organizations or educational associations, cultural and religious under national law, to require voluntary financial contributions and other contributions, including public assistance (32.2);

- Professing and practicing their religion (32.3);

- Establish and maintain unimpeded contacts among themselves in their country, and across frontiers with citizens of other states who share ethnic or national origin, cultural heritage or religious beliefs (32.4);

- Dissemination and exchange of information in their native language, and access to information (32.5);

- Create and maintain organizations or associations in their countries and international non-governmental organizations participating in activities (32.6).

\footnotetext{
${ }^{4}$ Name the OSCE dates back to January 1, 1995, following the decision of the Budapest Summit in December 1994. For details about the historical aspects of protection of national minorities in the OSCE see Jan Helgesen, 'Protecting Minorities in the Conference on Security and Cooperation in Europe (CSCE) Process ", p. 159-186, in Allan Rosas and Jan Helgesen (eds), The Strength of Diversity: Human Rights and Democracy pluralistic, Dordrecht 1992, Martinues Nijhoff Publishers.

5 Document of the Copenhagen Meeting of the CSCE Conference on Human dimension in Security and Cooperation in Europe. Documents (1989-1992), edited by Valentin Lipati edition and Ion Diaconu Lipati, Romanian Academy Publishing House, 1993, p. 35.
} 


\section{- OSCE IN DECEMBER 1994)}

Another category of provisions contained in the final document refers to the obligations of participating states to ensure the protection of ethnic, cultural, and religious minorities lingivistice their territory and create conditions suitable for promoting this identity, in accordance with the principles of equal rights and discrimination against other citizens of the participating State concerned (P. 33).

Thus, in terms of education, provided that the participating States will strive to ensure that persons belonging to minorities, will be outside the duty to study the language of the State the opportunity to learn their mother tongue or to be able to teach in that language and, if possible and necessary, to use language in relations with public power, according to national legislation (point 34).

It also stipulates the right of persons belonging to national minorities to participate effectively in public affairs, especially in activities concerning the protection and promotion of the identity of these minorities (point 35). The same document provides required participating States to promote the establishment of a favorable climate of understanding and mutual respect among all citizens regardless of ethnic or national origin (point 36, paragr.2). There are convicted in the content of that act, racial and ethnic hatred, anti-Semitism, xenophobia and discrimination or persecution, participating States declaring its determination to intensify efforts to combat these phenomena and to this end to take action against any act of violence based on national discrimination or hatred, to take measures to protect such persons against such acts, to promote understanding and tolerance (point 40).

Sustain attention in the context of the Final Document presented and provisions outlining policy and international law limits the exercise of the rights of national minorities.

In this respect, at point 37 states that none of the commitments set can not be interpreted as leading to any right to undertake any activity or perform any act contrary to the purposes and principles of the Charter of the United Nations, other obligations of international law or provisions of the Final Act, including the principle of territorial integrity of states.

Meeting in Geneva from July 1 to 19, 1991, devoted to the minorities, reiterated in the document adopted, that human rights and fundamental freedoms is the protection and promotion of national minorities. ${ }^{6}$

Within that after they showed qualitative changes recorded on the continent, participating States have taken note of the positive results obtained in a number of countries and stressed that "there may be different approaches to implementing their CSCE commitments corresponding to the problem of national minorities".

It was also reiterated the importance of active participation of persons belonging to minorities in public life as a component of democracy.

It was also stressed that full equality of rights with the majority of particular concern and requires special measures taken by States Parties.

Promoting the rights contained in the Final Document of the Copenhagen Meeting Report from Geneva, in turn developed new approaches, as follows:

- participating States states that national minorities will enjoy the same rights and duties will have the same citizenship as the rest of the population;

- the problem of minorities is recognized to be an international issue;

- are protected equally and those belonging to the majority in that State, but in some areas are minority;

- freedom to maintain ties with citizens of other states, the same ethnicity, culture or faith. This will encourage cross-border cooperation at all levels.

\section{Rights protection mechanisms identity of national minorities in the Organization for Security and Cooperation in Europe.}

\footnotetext{
${ }^{6}$ Report of the Meeting C.S.C.E. Expert in minority issues, Geneva 1991, Security and Cooperation in Europe documents, 1989-1992, p. 110.
} 
In the context of mechanisms to protect the national minorities, noted the establishment by the Conference for Security and Cooperation in Europe, during the meeting HelsinkiEuropean in 1992, the High Commissioner on National ${ }^{7}$ Minorities Institution.

High Commissioner operates under the aegis of the Committee of Senior Officials as a means of conflict prevention at an early stage.

The High Commissioner's mandate specific functions are included as assurance that an "early warning" and if necessary, an "early action", the latter being applied in an early stage as related to stress related national minority issues which have not yet passed the stage of early warning, but, according to High Commissioner, are likely to escalate into conflict.

In exercising its powers acting High Commissioner confidential and independent of all parties. It receives information from any source (excluding individuals or groups that practice terrorism), assesses the role of stakeholders as soon as the nature of stress as possible consequences for peace and stability in the OSCE area It also can visit any participating State, after consultation with the State, staff can communicate with the parties and, where possible, to promote dialogue and trust between them.

If there is a potential for conflict, the High Commissioner may initiate an early warning that a President communicate in the Office of the CSCE, it will submit to the Committee of Senior Officials (first session).

It can also be authorized to recommend to the sense of coming into contact and consultation with stakeholders, aiming to find possible solutions. When you consider that a situation is about to degenerate into a conflict and its possibilities of action are exhausted, it shall inform the President of CSCE It is forbidden to engage in the examination of individual cases of human rights violations.

High Commissioner cooperates in fulfilling its mission to international organizations and institutions like the United Nations, World Bank, Council of Europe and the European Commission.

\section{Conclusions}

The analysis performed shows that in the European plan to involve regional institutions, among which the CSCE / OSCE, led to the obvious evolution of consecration of regulations and protection of rights of minority identity is taken on the issue of legal and political documents more because adequate detail and institutionalization of norms and procedures relating to the matter mentioned.

OSCE documents submitted attesting that the promotion and protection of European identity rights of persons belonging to national minorities are part of human rights protection system developed at the United Nations under the universal, namely, the Regional Council of Europe, Organization for Security and Cooperation in Europe and other European institutions.

Although international acts dealt with in this material develops a good deal, paying particular attention to human rights catalog rights for persons belonging to national identity, yet they do not impose legal obligations states have adopted.

They determine the programmatic direction but the matter of consecration and protection of rights of persons belonging to national identity, being a political instrument effectively. In context, it is significant that some countries that participated in the documents introduced in their national standards of the kind imposed by the OSCE on issues mentioned, giving them indirectly and necessary legal force.

OSCE documents analyzed circumscribed acts that form the human dimension, as well as other regulatory and industry (universal or regional), which aims to protect the rights of consecration and identity of persons belonging to minorities ational does not authorize any activity that is contrary to fundamental principles of international law, provided the United

\footnotetext{
${ }^{7}$ See Security and Cooperation in Europe, 1989-1992 Documents, p. 186-190.
} 
Nations Charter, or other obligations under international law or provisions of the Helsinki Final Act, in particular the principle of sovereignty and territorial integrity of states.

Establishment of the institution by OSCE High Commissioner on National Minorities has been establishing an instrument for ensuring security in Europe through the establishment and warning in as early a stage, on the situation of minority identity rights violations which could lead to conflicts in the OSCE region.

In conclusion, we appreciate that although the procedure established by the OSCE in promoting and guaranteeing the rights of persons belonging to national identity is the great political, and its provisions on human dimension, not treated, they express the will of the States which have participated in the to their moral and political force and to engage to respect the rights of the category listed.

\section{Bibliography}

Niciu I. Marbian, Drept international public, Servosat Publishing House, Arad, 2004

Tanasescu Tudor, Drept international public, University Course, Sitech Publishing House, Craiova, 2013

Tanasescu Tudor, Minorities. Institutional and legislative frames, Sitech Publishing House, Craiova, 2006

Helgesen Jan, Protecting Minorities in the Conference on Security and Cooperation in Europe (CSCE) Process, in Allan Rosas and Jan Helsegen (eds) The Strength of Diversity: Human Rights and Pluralist Democracy, Dordrecht 1992, Martinues Nijhoff Publisher

Document of the Copenhagen Meeting of the Conference on the Human dimension of the CSCE, in Security and Cooperation in Europe. Documents (1989-1992), edited by Valentin Lipati edition and Ion Diaconu, Romanian Academy Publishing House, Bucurersti 1993

Report of the CSCE Meeting of Experts on National Minorities Issues, Geneva 1991, in Security and Cooperation in Europe. Documents (1989-1992)

Concluding document of the Vienna Meeting of the representatives of States participating in the Conference on Security and Cooperation in Europe, Nicolae Balcescu Publishing House, Bucharest 1990. 